\title{
Violência e paz na vida e obra de Thomas Merton
}

Getúlio Bertelli

\section{Introdução}

Em 2008 lembramos os quarenta anos da morte martirial de Thomas Merton (1915-1968). O presente artigo quer prestar uma singela homenagem à sua memória, destacando um dos temas prioritários de sua vida e escritos. Merton foi um mestre em espiritualidade, e formador de opinião, ensinando o mundo a unir contemplação e ação. Sua vida foi marcada por uma clara evolução espiritual, ou seja, por uma dupla conversão: do mundo ao mosteiro, e outra vez do mosteiro ao mundo, sem perder sua vocação monástica, sacerdotal e eremítica. Nos primeiros dez anos desde a publicação de sua auto-biografia em 1948, intitulada A Montanha dos Sete Patamares ${ }^{1}$, Merton acentua o paradigma da fuga do mundo (fuga mundi). Entende a mística como um subir a montanha de Deus. Em 1958 ele experiencia uma crise espiritual, uma mudança de valores e perspectiva: começa, então, a descer a montanha de Deus, numa abertura ao mundo movido por compaixão.

A evolução espiritual de Merton tem o seu ponto de inflexão em 1958, a partir da experiência no centro de Louisville, Estado do Kentucky, EUA. Em pleno centro comercial, atrás da Catedral Nossa Senhora da Assunção, Merton percebe como que num momento de iluminação, que os votos monásticos não o separaram do mundo, mas o aproximaram ainda mais dele;

\footnotetext{
${ }^{1}$ MERTON, Thomas, The Seven Storey Montain. Harcourt Brace e Companhia, 1948. (Tradução brasileira: A Montanha dos Sete Patamares. Petrópolis, Vozes, 2005.
} 
que ele próprio é parte da família humana, tão amada por Deus e tão ameaçada pela violência presente na sociedade, na cultura e na religião. Uma tal experiência aprofundou sua experiência de Deus e dos humanos, imprimindo profundidade aos seus escritos. Coincide também com o início do pontificado de João XXIII naquele mesmo ano, inaugurando uma maior abertura da Igreja ao mundo. Começa então a se encontrar com os problemas do mundo, dentre os quais o mais grave é o da ameaça da guerra, e o conseqüente empenho em promover a paz ${ }^{2}$.

Em 1961, quando da invasão da Baía dos Porcos, em Cuba, pelas tropas norte-americanas, Merton escrevia à sua grande amiga Dorothy Day: "Sinto que num tempo como o nosso, em sã consciência, não posso continuar escrevendo coisas como meditação, embora tenha sua importância, nem sobre estudos monásticos secundários. Penso que devo enfrentar os grandes problemas atuais, que são questão de vida e de morte. E é isso que todos temem"!

\section{O encontro de Merton com os grandes problemas atuais 1. Um mundo de VIOLÊNCIA}

Merton se pergunta: Será que a violência política e religiosa é um fato que devemos tomar como banal e corriqueiro? Será a fé um narcótico que nos ajuda a conviver com a violência sem opor resistência? Como pode ser que os seguidores do Príncipe da Paz, ao longo da história, tenham se mostrado tão sanguinários? Por que, ao invés de usarem a estratégia evangélica da não violência na solução dos conflitos internacionais, preferem o recurso às armas letais? ${ }^{4}$

Assim como o mundo de Bernardo de Claraval, (um dos Pais de Cister, em cuja ordem Merton ingressou), e o de Juliana de Norwich, (que o abriu para a dimensão feminina em Deus), foram marcados pela violência das cruzadas e outras guerras, com todas as seqüelas daí decorrentes, assim também o mundo que Merton redescobre é marcado pela canonização da violência como solução aos problemas em todos os níveis da convivência humana, nomeadamente na sociedade e cultura norte-americanas.

\footnotetext{
${ }^{2}$ HALL, Gary Peter. From 'Contemptus Mundi' to Real Presence. Thomas Merton's Relation to the World: A Study in Moral Development. Dissertação de Mestrado. Birmingham, University of Birmingham, 1994.

${ }^{3}$ MERTON, Thomas, The Hidden Ground of Love: The Letters of Thomas Merton on Religious Experience and Social Concerns. San Diego, Hartcourt Brace Jovanovich, 1993. Carta a Dorothy Day de 23/ago/1961, p.139-140 (abreviado HGL).

${ }^{4}$ MERTON, Thomas, Paz na Era Pós-Cristã, Testamento de um dos Maiores Místicos do Século XX. Aparecida: Editora Santuário, 2007, p.23- 81; 116ss.
} 
Grande parte das obras mertonianas trata da violência, enquanto recurso à solução dos problemas internacionais, isto é, da violência como norma (cânon). Em outros termos, trata da violência como decisão política dos governantes. Dois presidentes em especial são citados, aos quais Merton reserva bem poucos elogios: Harry Truman e Lyndon B. Johnson ${ }^{5}$.

Harry Truman tornou-se presidente dos EUA em abril de 1945. Seu nome está ligado à explosão das bombas atômicas sobre a população civil de Hiroshima e Nagasaki. A primeira bomba levou seis anos para ser produzida, ao custo de dois bilhões de dólares. Um grupo de cientistas alertou que o uso da bomba numa guerra seria de difícil ou impossível controle. Sua explosão no deserto do Novo México foi comemorada com devoção e com uma citação bíblica para confirmar os que duvidavam de seu desempenho, como o desconfiado e descrente almirante Leahy: "Senhor, eu creio, mas aumenta a minha fe". 6

Merton escreveu, cheio de indignação ética, sobre a obscenidade da bomba e o sacrilégio que a circunda. Assim, o primeiro teste nuclear no deserto de Almagordo, Novo México, foi chamado de "Trindade". Esse sacrilégio parece dizer a Deus: O que você criou, nós agora conseguimos destruir, num gesto de "des-criação". Um sentimento quase religioso envolveu a preparação, transporte e uso da bomba, levada em procissão reverente até o avião Enola Gay em 6 de agosto de 1945. ${ }^{7}$

Merton escreveu o poema intitulado: "Bomba: Criança Original", a respeito do lançamento da bomba atômica sobre Hiroshima. Trata ironicamente a bomba como uma "criança original", nascida em 1945, e lançada sobre uma cidade sem importância militar, matando cerca de 70.000 civis de imediato. Outras cidades foram cogitadas como alvo, como Kyoto e Tóquio, mas tal opção foi descartada, em favor de Hiroshima. Merton sente indignação ética diante da profanação e do sacrilégio da linguagem religiosa ligada à bomba. Assim, não só o primeiro teste atômico secreto foi chamado de "Trindade", quanto a missão de lançamento sobre Hiroshima, a partir de Tinian, foi chamada de "Papado". 8

\footnotetext{
${ }^{5}$ MERTON, Thomas, The Collected Poems of Thomas Merton, Nova Iorque, A New Directions Book, 1980, p. 293ss (abreviado CPTM).

${ }^{6}$ CPTM 297, Não muito longe do deserto de Almagordo, no Novo México, onde se testou a primeira bomba atômica, foi fundado um mosteiro contemplativo chamado "Cristo no Deserto". Merton lá esteve antes de sua viagem ao oriente. Ao voltar, pretendia ingressar nesse mosteiro, talvez em reparação moral por esta tragédia para a humanidade. Mas a morte o surpreendeu em Bangcoc, em 10 de dezembro de 1968.

${ }^{7}$ MERTON, T., Original Child Bomb, Nova Iorque, A New Directions Book, 1962, p. 7.

${ }^{8}$ FOREST, Jim, Living with Wisdom: A Life of Thomas Merton, $2^{\mathrm{a}}$ ed., Nova Iorque, Orbis Books, 1992, 134-135 (abreviado $L w W$ ).
} 
Quase duas décadas depois, os EUA com o presidente Lyndon B. Johnson se envolveram na Guerra do Vietnam. A guerra e a crise dos mísseis em 1962, no auge da Guerra Fria, despertaram definitivamente a consciência de Merton para o fato de que vivemos numa era nuclear. Desabafando, ele pergunta aos ativistas antinucleares: Como a Igreja pode ser tão intolerante na questão do controle da natalidade, e não condenar com a maior veemência as armas de destruição em massa, capazes de acabar com o Planeta inteiro? ${ }^{9}$

Merton considera a decisão de Johnson de invadir o Vietnam como um absurdo e uma estupidez sem tamanho, apoiado na ignorância crassa do Departamento de Estado. Mesmo que ele se retire de lá, humilhado por flagrante derrota, o mal cometido terá sido uma loucura irreparável, revelando a capacidade de violência, injustiça e estupidez de que sua nação é capaz. ${ }^{10}$ Em sua arrogância ditatorial e imperialista, Johnson transformou a nação num estado policial. Ele não ouve ninguém que discorde de sua política, mesmo perdendo o apoio das nações civilizadas do mundo e ante a perspectiva de uma guerra prolongada por décadas. Ele não ouve a opinião das pessoas experientes, nem sequer o Papa. ${ }^{11}$

Durante a $1^{\mathrm{a}}$ e $2^{\mathrm{a}}$ Guerras Mundiais, em ambos os lados beligerantes havia cristãos lutando uns contra os outros, com o aval das hierarquias católica, ortodoxa e protestante. As exceções foram bem poucas (merecem destaque Dietrich Bonhoeffer, Simone Weil, Franz Jäggerstätter e Alfred Delp, entre outros ${ }^{12}$ ). Vamos desdobrar a seguir, um dos problemas mais urgentes enfrentados por Merton, a saber: a canonização da violência no mundo atual.

\subsection{A canonização da violência}

Quando Merton despertou para a compaixão, na experiência do centro comercial em Louisville em 1958, em sua nova abertura ao mundo, descobriu que a sociedade americana, que ele tinha deixado para trás, é essencialmente violenta e caótica, apesar de aparentemente bem ordenada e cortês. Essa violência congênita já vem do passado, de suas raízes colonialistas e belicistas, do mito do "destino manifesto" (estendendo as fronteiras de mar a

\footnotetext{
${ }^{9}$ RUSSEL, John. Thomas Merton: Celebrity monk. Disponível em: http://www.abc.net.au/rn/relig/enc/stories 322192.shtm, p 8-18. Acesso em 6/dez/02.

${ }_{10}$ MERTON, Thomas, The Courage for Truth: Letters to Writers. Nova Iorque, Farrar, Strauss e Giroux, 1993, p. 150-151 (abreviado CT). Parece que essa lição do passado foi esquecida hoje!

${ }^{11}$ CT 158 .

${ }^{12}$ MERTON, Thomas. Faith and Violence: Christian Teachings and Christian Practice. Notre Dame, University of Notre Dame Press, 1968, p. 3-20 (abreviado $F V$ ).
} 
mar, do Atlântico ao Pacífico), violentando os indígenas, roubando suas terras e promovendo guerras de conquista. Quando as fronteiras para o oeste foram conquistadas, os EUA se voltam para o sul. Agora tentam dominar o mundo inteiro, mediante a guerra, o comércio injusto, a ideologia neoliberal e a cultura consumista do aqui e agora, bem como através de uma religião que é só um verniz de cristianismo, e de uma moralidade que é só moralismo. Com o passar dos anos a violência imperialista só se acrescentou, podendo no futuro levar à autodestruição do império, homicida agora, e suicida depois. ${ }^{13}$

Merton detecta as causas dessa enfermidade na própria cultura norteamericana, em sua mídia, seus mitos de superioridade, seu espírito de competição. Ele considera hipócrita a atitude do governo de pretender impor a democracia e a liberdade no mundo inteiro, sob a mira de canhões e mísseis atômicos. Por isso o governo norte-americano perdeu credibilidade no concerto das nações. Essas percebem as contradições: o homem branco americano defende mais o lucro do que as pessoas, o livre comércio mais do que pessoas livres. ${ }^{14}$ Para Merton a Guerra do Vietnam era uma manifestação visível dessa violência estrutural permeando a sociedade americana inteira e transferida aos outros continentes ${ }^{15}$. Colonialistas brancos invadiram as terras dos amarelos, vitimando-os com bombas napalm e os considerando como seres inferiores, como fizeram com os negros dentro do seu país.

Os EUA entraram na Guerra do Vietnam, não porque a nação estivesse ameaçada, mas buscando conquistar a supremacia mundial e defender os interesses das grandes corporações. ${ }^{16}$ Destarte, o governo foi e é incapaz de considerar a guerra como um engano e crime. Merton fez ouvir claramente sua voz de protesto contra essa violência atroz que ceifou a vida de cerca de 30.000 jovens enquanto ele estava vivo. Foi o maior erro da historia militar, de conseqüências devastadoras para crianças, mulheres e adultos, bem como para o meio ambiente. $\mathrm{O}$ resultado final só podia ser contraproducente, ge-

\footnotetext{
${ }^{13}$ BAKER, Thomas James, Thomas Merton Social Critic, Lexington, The University Press of Kentucky, 1971, p. 112.

${ }^{14}$ MERTON, Thomas, Seeds of Destruction, Nova Iorque, Farrar, Strauss and Giroux, 1962, p.22-28 (abreviado $S D$ ).

${ }^{15}$ MERTON, Thomas, Dancing in the Water of Life: Seeking Peace in the Hermitage, Nova Iorque, Harper Collins, 1998, 203-204 (abreviado DWL).

${ }^{16}$ No novo Vietnam de hoje, que é a Guerra do Iraque, vigora a mesma lógica: por trás de uma pretensa ameaça aos EUA, estão interesses econômicos de poderosas companhias armamentistas e petrolíferas, cujos sócios são o presidente Bush e seu staff (Dick Cheney e Rumsfeld) como revela com clareza meridiana o documentário de Michael Moore, Farenheit 11 de Setembro. Eles são os únicos a lucrar com a guerra, e são a antípoda da compaixão, genocidas e inimigos de Deus e da humanidade.
} 
rando antiamericanismo e levando a Ásia a se tornar comunista. Destarte, Merton considera a guerra pura e simplesmente como uma celebração demoníaca, uma anti-festividade e uma anti-celebração, por excelência. ${ }^{17}$

Merton considera ainda chocante a atitude do Cardeal Francis Spellman de Nova Iorque, abençoando os canhões que iriam destruir milhares de vidas humanas, crianças, mulheres e adultos no Vietnam ${ }^{18}$. O sucessor de Spellman também estava no Vietnam como Almirante da Marinha dos EUA. Essa cumplicidade e conivência da hierarquia católica com a violência se revelavam também na ausência de qualquer denúncia profética. Ao contrário, os pronunciamentos oficiais da hierarquia eram a favor da guerra. Nas escolas e Igrejas Católicas havia a seguinte inscrição: "pro Deo et pro patri$a^{\text {"19. }}$. A intromissão da bandeira norte-americana em todas as Catedrais, Igrejas e Capelas é um sinal evidente de que se trata antes de uma "religião civil" e não da fé cristã autêntica.

Merton considera que seria uma caricatura de obediência submeter-se às idéias de um homem como o Cardeal Spellman, rico, gordo e cheio de preconceitos e interesses nacionalistas ${ }^{20}$. Como católico, o Eremita de Gethsemani sentiu-se "um espectador culpado" diante da obscenidade e canonização da violência. Sua voz representava uma honrosa exceção (mais tarde silenciada por seus superiores). E, por influência direta de Merton, Daniel Berrigan e John Dear, dois jesuítas, encarnam a resistência não violenta cristã hoje. São os maiores apóstolos e profetas denunciando a guerra atual ${ }^{21}$.

Merton escreveu uma carta aos bispos da América do Norte no momento estratégico em que estes voltavam a Roma para a segunda sessão do Concílio Ecumênico Vaticano II em 1965. Na Carta buscava convencê-los a condenar por todos os meios o uso das armas atômicas como sendo imoral e anticristão, considerando as vítimas civis inocentes. Deixemos que ele mesmo se manifeste: "Os governantes continuam a investir a maior parte do orçamento em armas e na preparação para a guerra e continuam a mostrar uma acentuada preferência por resolver as disputas internacionais mediante a violência e a ameaça da violência, ao invés de usarem meios pacíficos e racionais... É o primado do poder e da violência. Parece que a ameaça terrorista da violência continuará entre nós como traço permanente da nossa civili-

\footnotetext{
${ }^{17}$ MERTON, T., Cistercian Studies. v. I, 1966, p. 109.

${ }^{18}$ HGL 114 .

${ }^{19}$ MERTON, T., Paz na Era Pós-Cristã, Op., Cit., p. 8.

${ }^{20}$ MERTON, T., Turning toward the World: The Pivotal Years, Nova Iorque, HarperCollins, 1997, p. 178 (abreviado TtW).

${ }^{21}$ Cf., Atualidade Teológica, PUC-Rio, Ano IX, fasc. 21, 2005, p.274-294.
} 
zação". ${ }^{22}$ Grande parte do que Merton escreveu nas chamadas Cartas da Guerra Fria foi depois incorporado pelo próprio Concílio!

\subsection{As Cartas da Guerra Fria}

Foi a partir de outubro de 1961 (quando escreveu sua primeira carta a Etta Gullik - que se confiara ao seu cuidado pastoral - sobre a Guerra Fria), até outubro de 1962 (quando foi silenciado pelo abade geral Dom Gabriel Sortais), que Merton elaborou melhor sua resposta ao gravíssimo desafio da violência. Era então o auge da Guerra Fria entre os EUA e a URSS. Era também o início do Concílio Vaticano II (1962-1965). Submetido a um silêncio obsequioso, Merton não deixou de escrever. Ele secretamente escreveu 111 cartas, recolhidas pelos amigos e publicadas sob o título "As Cartas $d a$ Guerra Fria". Muitos Padres Conciliares receberam exemplares dessas cópias.

Vemos ressonâncias dessas cartas na elaboração da Constituição Gaudium et Spes, sobretudo nos parágrafos 77-82, que tratam especificamente da corrida armamentista, da política de dissuasão e da guerra nuclear como crimes contra Deus e a humanidade. ${ }^{23}$ Merton escreveu para o jornal fundado por Dorothy Day, O Trabalhador Católico, um artigo (que acabou sendo polêmico), sobre a loucura da guerra. Afirma que "todos enlouqueceram, construindo abrigos nucleares, e preparando-se para atirar nos vizinhos... Basta disparar um alarme falso e nós mesmos nos mataremos uns aos outros a tiros... Prova perfeita de democracia e individualismo". ${ }^{24}$

Já em 1962, por ocasião da presença dos mísseis russos em Cuba, ponto mais alto da tensão a que chegou o conflito EUA x URSS, Merton percebeu claramente que seu país era vulnerável, capaz de ser atingido por uma devastação que, segundo ele, viria em três ou cinco anos. O acúmulo de armas tornaria quase inevitável seu uso, seja intencional, seja acidental. Destarte, Merton incorpora essa perspectiva apocalíptica em sua espiritualidade monástica, e nunca mais a deixa. Em conseqüência, ele se propõe alguns objetivos, entre os quais o primado da "compaixão por todos os seres vivos, pela vida, pelos simples e indefesos, pela raça humana em sua cegueira". ${ }^{25}$

\footnotetext{
${ }^{22}$ MERTON, T., Carta Aberta à Hierarquia Norte-Americana, $W F 89$.

${ }^{23} \mathrm{TtW}$ 169-216.

${ }^{24}$ HART, Patrick e MONTALDO, Jonathan (orgs), Merton na Intimidade, Sua Vida em seus Diários, Rio de Janeiro, FISUS, 2001, p. 214 (abreviado MnI).

${ }^{25}$ MnI 221.
} 
Interpelado sobre a Guerra do Vietnam, Merton afirma que esta não tinha como objetivo defender o povo vietnamita, mas para destruí-lo; tampouco defender os interesses americanos, pois acabou gerando um antiamericanismo generalizado; nem mesmo para barrar o avanço do comunismo, pois acabou jogando a população do lado dos vietcongs (comunistas) como dissemos anteriormente. A causa de tanta beligerância é que o governo está iludido com seus mitos e quer fazer a sociedade acreditar neles. Mito da liberdade? Da superioridade norte-americana sobre os demais povos? Seja como for, Merton pressente que Deus irá julgar severamente a nação por sua soberba e pretensões imperialistas. ${ }^{26}$

Como remediar o problema devastador da violência no mundo atual? A resposta de Merton foi profética, feita de bênçãos e maldições. Ele não usou de meias palavras, por isso sua atitude incomodou muita gente. O que ele propõe como solução à canonização da violência é a resistência cristã não violenta ${ }^{27}$. Essa é a resposta não só frente à violência, quanto frente à injustiça. Tem como paradigmas a figura de Jesus, Gandhi, King, Simone Weil, Delp e Jägersttater ${ }^{28}$, entre outros.

Merton apelou para que a sociedade americana abandonasse seus mitos de superioridade, sua atitude de faroeste, e assumisse os ideais de justiça e $\mathrm{paz}^{29}$. Malgrado os governantes, a hierarquia católica e o povo continuarem apostando na eficácia da violência como solução aos problemas domésticos e internacionais, a resposta de Merton ajudou a lançar as bases de um programa de ação social e a despertar a consciência adormecida de muitos católicos e não católicos.

Mas isso teve um preço. Merton sentiu na própria pele as conseqüências de seu testemunho profético contra a violência e a favor da paz. Em uma Carta ao seu grande amigo e ex-noviço Ernesto Cardenal, ele desabafou dizendo: "Você sabia que alguns católicos fanáticos em Louisville queimaram os meus livros, e declararam que eu sou ateu por resistir à Guerra do Vietnam? Esse país está enlouquecido com ódio, frustração, estupidez e confusão... Eu sentiria vergonha indo a um país da América Latina e ser reconhecido como cidadão norte-americano". ${ }^{30}$

Mais de quatro décadas depois da redação de suas Cartas da Guerra Fria, a canonização da violência e a corrida armamentista continuam entre

${ }^{26}$ DAGGY, Robert (org.), The Road to Joy: Letter to New and Old Friends, Nova Iorque, Hartcourt Brace Jovanovich, 1993, p. 360 (abreviado RJ).

${ }^{27} \mathrm{Tt} W$ 69, 111, 126, 172, 238-239.

${ }^{28} \mathrm{Tt} W 213-214$.

${ }^{29} \mathrm{Tt} W 2 \mathrm{~W} 2 \mathrm{-244}$.

${ }^{30}$ CT 161 . 
os maiores problemas do mundo de hoje. Sem dúvida, a corrida armamentista constitui a maior crise da cultura contemporânea, constituindo uma ameaça para a vida, as instituições e todas as criaturas da Terra. João Paulo II reiteradas vezes a denunciou como obstáculo ao bem estar na América, consumindo "enormes somas de dinheiro que deveria ser, pelo contrário, destinado a combater a miséria e a promover o desenvolvimento". ${ }^{31}$

Eis o que Merton encontrou ao descer a montanha de Deus, movido por compaixão pela humanidade, em sua abertura ao mundo: a violência endêmica da sociedade norte-americana, interpelando-o como contemplativo ao desafio da paz.

\section{O Desafio da PAZ}

\section{Explorando a dimensão contemplativa do Evangelho}

A mística mertoniana é profundamente bíblica e em especial, é evangélica. A chave para sabermos se a mística é autenticamente evangélica é a capacidade de criar compaixão e abertura, que são ações iluminadas e brotadas da contemplação. Merton busca extrair da Bíblia, particularmente do Evangelho, toda a base para construir o Reino de Deus, uma nova sociedade. "Descobrir todas as implicações sociais do Evangelho, não as estudando, mas sim as vivendo, e unir-me explicitamente àqueles que antevêem e trabalham por uma ordem social - uma transformação do mundo de acordo com estes princípios: primado da pessoa (daí justiça, liberdade, anti-escravidão, paz, controle da tecnologia, etc.). Primado da sabedoria e do amor (daí antimaterialismo, hedonismo, prepotência, etc.)".32 A espiritualidade da paz é um desafio que brota da mensagem de Jesus no Sermão da Montanha.

\subsection{No Sermão da Montanha: "Felizes os Construtores da Paz" (Mt 5,9)}

O Evangelho inteiro é base para a mística mertoniana. Mas, diante das perguntas implícitas na situação atual, ele ressalta aquelas perícopes que projetam mais luz para responder aos desafios da hora presente. Por exemplo, é recorrente em seus escritos a ética das Bem-Aventuranças como iluminação para o agir cristão. No Sermão da Montanha como um todo, Jesus alude à contemplação de Deus como bem-aventurança final ("verão a Deus"). Ser perfeito é imitar a compaixão de Deus (rahâm, já presente em Ex 34,6). Compaixão aparece em Lucas 6,36, oiktirmôn, significando a ter-

\footnotetext{
${ }_{31}^{31}$ João Paulo II, Ecclesia in América. Exortação Pós-Sinodal, São Paulo, Loyola, 1999, p. 69.

${ }^{32} \mathrm{MnI} 180$.
} 
nura de Deus para com as suas criaturas. O Pai compassivo que, em sua bondade faz o sol nascer sobre justos e injustos, pede que imitemos sua atitude compassiva. Eis onde reside a perfeição cristã, que o monge busca mais do que qualquer outro cristão! Ela é a glória de Deus ("a glória de Deus é o homem vivente"), na bela expressão de Santo Irineu ${ }^{33}$.

A perfeição cristã proposta no Sermão da Montanha consiste então, no abandono confiado e gozoso, a partir da própria fragilidade e indigência, nas mãos de Deus. É o reflexo da compaixão e da glória de Deus no ser humano. Deus mesmo toma a iniciativa de mostrar-nos a nossa fragilidade, num processo de purificação passiva, vencendo nossos pretensos êxito-vanglóriaafirmação, pela compaixão que Ela sente pela nossa fragilidade. ${ }^{34}$ Unicamente assim o ser humano é capaz de se abrir à fragilidade e indigência de seus irmãos, movido por compaixão. Ele é capaz, então, de deixar de lado toda a crítica, revolta e isolamento frente aos outros.

A prática da resistência não violenta ensinada e vivida por Merton é decorrente dessa compaixão e dependente da Palavra de Deus nas Bem Aventuranças. Compartilha da impotência de Deus junto às vítimas e se solidariza com os excluídos do mundo. Muito antes que a Teologia da Libertação latino-americana fosse elaborada, Merton ensina que ser não violento é ser solidário com os pobres do Terceiro Mundo ${ }^{35}$. Não violência é a atitude de compaixão, unida à coragem e sabedoria.

\subsection{Promover a paz}

O empenho de Merton em promover a paz se concretizou mediante seus escritos, conferências e ensinos, na qualidade de formador de opinião. Ele também projeta a estratégia para abolir a guerra: a não-violência como um estilo de vida, ampliando seu alcance para abranger também outras instâncias da vida, como o problema da injustiça sócio-econômica, de gênero e ecológica. Ele aprende tal estratégia com Gandhi, que por sua vez se inspirou no discurso de Jesus no Sermão da Montanha. Não é fraqueza, mas "uma força interior intensamente ativa e purificadora... O que se conquista pela espada, pela espada se vai perder... Minha arma mais potente é a oração silenciosa... A violência mental não tem poder, e envenena tão somente aquele que nutre pensamentos violentos... $\mathrm{Na}$ era da bomba atômica, a não violência

\footnotetext{
${ }^{33}$ Título de um belo hino cantado pelos monges trapistas de Tamié, na Savoia francesa.

${ }^{34}$ TS 76-79.

${ }^{35}$ CT 117.
} 
não adulterada é a única força capaz de confundir todos os enganos da violência" ${ }^{36}$ Eis aí alguns aspectos da dimensão espiritual da não violência!

Ao longo de seus escritos, Merton também cita várias vezes a Encíclica Pacem in Terris de João XXIII ${ }^{37}$, no sentido de buscar eliminar o medo (que está na raiz da guerra) e substituir os conflitos internacionais pela negociação e colaboração. Ele se pergunta: como seguidores de Jesus, o Príncipe da paz, o que nos incumbe fazer diante da crise atual? Tendo como base a doutrina da Encarnação, devemos substituir a reação de Caim e Judas pelo cuidado responsável pelos irmãos, nos quais devemos ver outros Cristos. Aqui está incluída a família humana inteira ${ }^{38}$.

Merton lembra que a Encíclica, lançada na Quinta Feira Santa de 1963, não se concentra tanto na violência da guerra, quanto nos princípios universais que devem nortear a convivência humana: o respeito pela dignidade da pessoa e de toda a família humana. O resultado deste pronunciamento do Papa foi o relaxamento das tensões entre os EUA e a URSS. De fato, a Encíclica busca animar a esperança em soluções pacíficas e condenar a violência destrutiva alimentada por suspeitas, desconfiança e demonização do inimigo, muitas vezes insuflada pela mídia. Daí a necessidade de resistir ao conformismo e à resignação fatalista que consideram a violência inevitável. ${ }^{39}$

Fazendo uma releitura da história da Igreja, Merton encontra ensinamentos sobre a promoção da paz em Orígenes e Agostinho. Orígenes tem uma atitude mais pacifista. Para ele os cristãos são promotores da paz no sentido mais radical. Em sua refutação a Celso (que acusa os cristãos de estarem destruindo o império romano), ele afirma que os cristãos fazem muito mais bem ao império com suas orações do que com as armas. Para ele as orações também são armas, mas não dirigidas contra outros seres humanos, e sim contra os poderes demoníacos que dividem a humanidade e incitam à violência ${ }^{40}$.

Agostinho, que viveu dois séculos mais tarde, em sua obra $A$ Cidade de Deus, considera o cristão como um soldado que deve defender sua pátria da invasão estrangeira ${ }^{41}$. Ele estava vivendo na época da invasão de Roma, pelos godos, (liderados por Alarico), e do Norte da África pelos bárbaros.

\footnotetext{
${ }^{36}$ MERTON, T., Gandhi on Non-Violence, Nova Iorque, New Directions, 1965, p.43-50.

${ }^{37} \mathrm{Tt} W 315,327$.

${ }^{38}$ MERTON, T., The Christian in World Crisis: Reflections on the Moral Climate of the 1960's, Redeeming the Time, Londres, Burns and Oats, 1966, p. 120s.

${ }^{39}$ Redeeming the Time, p. $126 \mathrm{~s}$.

${ }^{40}$ Redeeming the Time, p. 155.

${ }^{41}$ Citado em Faith and Violence: Christian Teaching and Christian Practice, Nore Dame, University of Notre Dame Press, 1968, p. IX-X, 4 (abreviado FV).
} 
Por isso ele desencoraja o soldado Bonifácio a entrar no mosteiro, mas aconselha a permanecer no exército para defender a pátria atacada. Agostinho entende que a ordem, montada no poder e no lucro, só o é em aparência, pois na verdade, faltando justiça, seus governantes são um bando de ladrões e salteadores ${ }^{42}$.

Merton escreve que a paz é dom e tarefa deixados por Jesus aos seus seguidores. "Cristo, nosso Senhor, não veio para trazer a paz como uma espécie de tranqüilizante espiritual. Ele trouxe aos seus discípulos uma vocação e uma tarefa: lutar no mundo de violência para estabelecer Sua paz não só no próprio coração, mas também na sociedade". ${ }^{43} \mathrm{O}$ seguimento de Jesus hoje vai consistir, então, em promover a paz num mundo armado até os dentes. Transformar espadas em arados, num mundo de violência imperial, exige uma fé profunda e a corajosa capacidade de auto-entrega martirial em favor dos outros.

Merton sabe que tentar implantar a paz com base na violência é contraditório e expressão de hybris. A paz não se consegue pela vitória, mas pela reconciliação. O Sermão da Montanha fornece a base teológica do agir cristão não violento. A compaixão divina é a inspiração maior. Um Deus desarmado e não violento convida os oprimidos a uma corajosa resistência ao mal, contando com a força de Jesus.

Em outubro de 1961 Merton escreve um artigo altamente incendiário para o jornal $O$ Trabalhador Católico, convocando os católicos à tarefa de abolir a guerra e buscar resolver os conflitos internacionais com a estratégia da não-violência ("satyagraha"). Aconselha a usar as armas espirituais da oração, vigília e jejum. Considera a guerra uma loucura, em cuja raiz está o medo. Ele não poupa acusações contra semelhante loucura generalizada, a pretexto de preservar a liberdade e os valores ocidentais. Considera a América do Norte a nação mais afetada por essa loucura, incluindo dentro dela os cristãos ricos e satisfeitos com suas posses e privilégios ${ }^{44}$.

O que fazer? Merton aponta a resposta: "Lutar com fé em Cristo, amor por Deus e pela humanidade para cumprir a única tarefa que Deus nos impõe no mundo de hoje: abolir totalmente a guerra... A Igreja deve conduzir o processo rumo à solução não violenta dos problemas e rumo à abolição gradual da guerra como forma de resolver disputas internacionais ou civis". ${ }^{5}$

\footnotetext{
${ }^{42}$ Redeeming the Time, p. 156.

${ }^{43}$ SHANNON, William (org.), Passion for Peace: The Social Essays, Nova Iorque, The Crossroad Publishing Company, 1997, p. 4 (abreviado PfP).

${ }^{44}$ PfP 315ss.

${ }^{45}$ PfP 12.
} 
Num tempo assim os cristãos não devem se resignar, em passividade e fatalismo, muito menos juntar-se aos que defendem um primeiro ataque preventivo para eliminar o inimigo antes que ele nos ataque, nem sair pelas ruas com o Livro do Apocalipse nas mãos explicando que tais acontecimentos já estavam escritos e são inevitáveis. Mas os cristãos devem fazer tudo para abolir a guerra, empregando meios não violentos, oração e sacrifício, e a ascese de buscar diariamente desarmar o próprio coração, não deixando a raiva transformar-se em violência. Eis aí a dimensão espiritual da não violência evangélica! ${ }^{46}$

Merton percebia, com pesar, que diante da extrema gravidade da hora presente, os monges eram incapazes de extrair da contemplação conseqüências para a ação. Eles estavam envolvidos com questiúnculas sobre textos medievais, enquanto a humanidade como um todo se debatia numa luta de vida e morte para todo o planeta. Ele não conseguia compreender. Mas apesar da resistência oficial, inclusive do abade geral Dom Gabriel Sortais (não por acaso ex-capelão militar na Primeira Guerra Mundial), Merton sente que sua atitude exprime a verdadeira posição cristã e católica ${ }^{47}$.

Muito do que Merton escreveu sobre a paz foi retomado pelo Papa João XXIII em sua encíclica Pacem in Terris. Com muita alegria por sentir que estava no rumo certo, mas não sem uma pitada de humor, (signo do verdadeiro contemplativo), ele escreve ao abade geral dos monges trapistas, Dom Gabriel Sortais, o mesmo que o havia impedido de escrever sobre a Guerra Nuclear em 1962: "Sorte que o Papa João não é um cisterciense norteamericano. Do contrário os censores da nossa Ordem nunca teriam aprovado a Encíclica do Papa sobre a Paz" ${ }^{48}$ No dia 7 de setembro de 1963, Merton recebeu a visita do teólogo Bernard Häring. Veio para animá-lo a escrever sobre a paz, em reparação pelo fato de São Bernardo ter pregado as Cruzadas. "Se um monge (no passado) foi capaz de pregar uma Cruzada, então um monge também (hoje) pode certamente escrever sobre a paz". ${ }^{49}$

Felizmente a posição do Cardeal de Nova Iorque, Francis Spellman sobre a legitimidade da guerra nuclear foi rejeitada na elaboração do esquema XIII do Concílio, como propunha Merton ${ }^{50}$. A Gaudium et Spes ${ }^{51}$, nos

\footnotetext{
${ }^{46}$ MERTON, Thomas, Gandhi on Non-Violence, op., cit., p. 43ss.

${ }^{47}$ MERTON, T., Paz na Era Pós-Cristã, Op., cit., p. 10ss.

${ }^{48}$ Cf., CUNNINGHAM, L., Silent Lamp: The Thomas Merton Story, Nova Iorque, Crossroad, 1996, p. 223 (abreviado $S L$ ).

${ }^{49}$ DWL $15-16$.

${ }^{50}$ DWL 317, 323.

${ }^{51}$ COMPÊNDIO DO VATICANO II: Constituições, Decretos, Declarações, $29^{\mathrm{a}}$ ed., Petrópolis, Vozes, 2000, p. 239ss.
} 
parágrafos sobre a eliminação da guerra (art. 77-82 p. 239-245) afirma: "Os homens de nosso tempo devem saber que prestarão contas de suas operações bélicas" (GS 241), ecoando assim palavras que quase quarenta anos mais tarde, João Paulo II dirige a Bush, com o dedo em riste, a propósito da Segunda Guerra do Golfo ${ }^{52}$. E mostrando onde se situa a paz, a Gaudium et Spes afirma: "A paz deve brotar antes da confiança mútua entre os povos, do que ser imposta às nações pelo temor das armas" (p.243). Assim, a lei da selva deve ser confrontada com as Bem-aventuranças no Sermão da Montanha.

Vamos ver a seguir a estratégia que Merton propõe para fazer frente à canonização da violência.

\subsubsection{Através da resistência não violenta}

Frente à canonização da violência no mundo contemporâneo, Merton propõe a prática da resistência não violenta. Ela é também a tática proposta para resolver os demais problemas sociais, como as várias formas de injustiça. Não é passividade, conivência, negação do mal ou covardia, mas uma atitude positiva e ativa. Ele começa reconhecendo que, em sua vida pessoal, nem sempre pratica a não violência. Pelo contrário, quando contrariado, faz retaliação em pensamentos e palavras contra os adversários que o tratam injustamente, e responde com um desprezo aberto e polido. Ele admite ter perdido muito tempo com desprezo, crítica e ressentimento inúteis. Destarte, ele se propõe ser modelo de não violência em palavra, ação e escritos. Às vezes a não violência supõe desobediência civil (e religiosa). Mas sempre supõe não cooperar com o mal. ${ }^{53}$

Merton sente-se só nessa tarefa. Ele é um precursor, e o faz à luz de sua fé e conviç̧ões mais profundas. Não foi nos manuais de teologia onde estudou que ele aprendeu a atitude de não-violência. Na época (década de 60) predominava, ao invés, a doutrina da Guerra Justa. Os católicos norteamericanos eram leais patriotas, considerando que, se os EUA entravam em guerra, era porque se tratava de uma "guerra justa". Foi com Gandhi que Merton aprendeu a metafísica da não-violência ${ }^{54}$, como já foi citado. Ele o conhecia já desde os tempos de estudante secundarista em Oakham, na In-

\footnotetext{
${ }^{52}$ Infelizmente, pouco depois, o secretário do Papa desmente essa atitude profética de condenação à Guerra do Iraque, alegando razões de Guerra Justa. Isso revela a aliança políticoeconômica da Igreja com os poderes econômicos que dominam a sociedade mundial, fazendo assim calar a voz da profecia, comprometendo gravemente a autenticidade do Evangelho.

${ }^{53}$ TtW 238-239.

${ }^{54} \mathrm{MnI} 185,395$.
} 
glaterra, em meados da década de 30. Ele concorda com Einstein, que considera Gandhi como "o pensador político mais eficiente e confiável de nosso tempo". 55

Merton admirava em Gandhi a síntese entre uma vida de profunda oração, contemplação e ascese por um lado; e, por outro lado, o engajamento ativo na libertação do seu povo, mesmo acarretando o martírio. "Ninguém consegue praticar a não violência de Gandhi, sem fincar fundas raízes espirituais na oração e na entrega a Deus". ${ }^{56}$ Admirava ainda a abertura de Gandhi às fontes cristãs, ao mesmo tempo em que permanecia firmemente arraigado em sua própria tradição hindu. E cita Gandhi quando diz: "Se trabalharmos com desapego e sem pressa, impediremos que algo nos ataque os nervos. Colocando o nosso coração por inteiro naquilo que nos foi confiado ou empreendido, podemos deixar o resto para Deus. Então não pode haver inquietação e nem pressa" ${ }^{57} \mathrm{E}$ assim nos livramos também do estresse.

Gandhi usa o método da não violência para combater as injustiças políticas, sociais e econômicas de seu país. Ele cunhou a expressão "satyagra$h a$ " para conotar o empenho pela paz e justiça sem o uso da violência, e o correlato termo sânscrito "ahimsa" (não ofender ninguém). Não é passividade, mas firmeza permanente no empenho por abolir a guerra, com amor incondicional pelo inimigo. ${ }^{58}$

Merton coloca algumas condições básicas para a prática da não violência. Em primeiro lugar, não ser conivente com a injustiça e a violência praticadas por um poder arbitrário e opressor. Em geral os defensores da causa não violenta estão nos países do Primeiro Mundo, e inconscientemente podem ser coniventes com o statu quo, que também os beneficia. Lutando na arena política, ele vê o risco de optar por um dos lados, e assim nem sempre ser capaz de ver a verdade também presente no adversário, e só endurecê-lo ainda mais em sua obstinação. Por outro lado, sendo apolítico, corre o perigo de ser ineficaz. É preciso também a paciência que vence o imediatismo de querer ver resultados visíveis. É preciso muita humildade para reconhecer que não somos infalíveis, e a capacidade de ceder em nossa posição inflexível, reconhecendo a verdade também presente no adversário, respeitando sua humanidade e visando o bem comum. ${ }^{59}$

\footnotetext{
${ }^{55}$ SfS 149.

${ }^{56} \mathrm{TtW} 111$

${ }^{57}$ CUNNINGHAM, Lawrence (org.), A Search for Solitude: Pursuing the Monk's True Life, Nova Iorque, HarperCollins Publishers, 1996, p. 156 (abreviado SfS).

${ }^{58}$ SHANNON, William. Something of a Rebel. Thomas Merton: His Life and Works, An Introduction. Cincinnati, St. Anthony Messenger Press, 1996, p.110 (Abreviado SoR).

${ }^{59}$ FV 3-13.
} 
Além de Gandhi, Merton admirava também outros apóstolos da nãoviolência, como Martin Luther King ${ }^{60}$, como já foi citado. Pretendia até convidá-lo para fazer um retiro na Abadia de Gethsemani em 1968, mas pouco tempo depois King foi assassinado. O mosteiro é o lugar ideal para reunir pequenos grupos de retirantes com objetivos afins, aprofundando a vida de fé e o compromisso libertador. Merton é adepto da estratégia da nãoviolência para deter a escalada de violência no mundo. Ele cita explicitamente como estratégias: desobediência civil, bem como oração, jejum e vigílias. $^{61}$

A não violência visa libertar não só o oprimido, mas também o opressor, vítima da violência. Para ele os negros devem libertar os brancos ${ }^{62}$. Não demonizar nem despersonalizar o adversário, mas com o olhar contemplativo cheio de compaixão, considerá-lo em sua dignidade. Ser não-violento, para Merton, significa ter a capacidade de sentir compaixão. Ela é o contraponto à tendência presente na política norte-americana atual de agressão internacional. Pois, como afirma o Eremita de Gethsemani: "A força genuína surge unicamente numa condição de vulnerabilidade. A manifestação ostensiva e o recurso à força são uma prova de profunda incapacidade". ${ }^{33}$

Podemos dizer que foi somente em 1965, com a publicação da Encíclica Gaudium et Spes, que cristãos mais ousados como Merton encontraram respaldo para sua atitude e prática de não-violência, mencionada naquele documento conciliar. Antes, porém, Merton se inspira no ensino de Jesus no Sermão da Montanha e na atitude de Gandhi, o qual, por sua vez, paradoxalmente, também se inspira em Jesus, como já foi citado. É parte da pedagogia e economia divinas que Deus revele Sua vontade através de não cristãos, num ensino assim tão fundamental para a convivência humana e para a sobrevivência do planeta. Tal ensino sempre esteve presente nos Evangelhos, mas não tinha sido totalmente desvelado. É o que afirmou Gandhi quando disse: "Unicamente os cristãos desconhecem que Jesus ensinou a não violência". 64

Vamos apresentar a seguir alguns modelos de resistência não violência propostos por Merton como inspiração e paradigmas para nós hoje.

\footnotetext{
${ }^{60} \mathrm{MnI} 198,369$.

${ }^{61} \mathrm{Tt} W 201$.

${ }^{62}$ PfP 198.

${ }^{63}$ MERTON, Thomas, Conjectures of a Guilty Bystander, Nova Iorque, Doubleday, 1989, p. VI-VII (abreviado $C G B)$.

${ }^{64}$ SoR 112.
} 


\subsection{Modelos de resistência não violenta}

Merton apresenta Jesus como o primeiro modelo de resistência não violenta, ao entregar sua vida livremente à morte, não fugindo por medo ou covardia ${ }^{65}$. Assumiu o sofrimento por acreditar que o mundo poderia ser diferente e melhor. Sofrimento, provação e martírio são inevitáveis para quem ousa nadar contra a corrente na busca de outro mundo possível.

Merton chama de Babilônia ao império montado sobre a violência dos poderes imperiais ${ }^{66}$. Os cristãos devem resistir a ela de forma não violenta, rompendo os laços. Mas eles não têm como fugir, senão pelo martírio como forma de protesto contra a idolatria da violência. A fumaça da ruína de Babel vai subir aos céus. Merton resgata assim a atitude dos primeiros cristãos diante do império romano. Não há indicativo de que eles lutassem para preservar o poder da besta, isto é, a favor do imperador ${ }^{67}$.

Merton aduz exemplo dos primeiros cristãos que praticaram objeção de consciência, resistindo ao serviço militar ou, quando nele, recusando a matar (São Maximiliano, São Martinho de Tours). O serviço militar foi rejeitado por Clemente de Alexandria. Cipriano nota que quando um indivíduo qualquer mata alguém é considerado criminoso, mas quando um governante mata milhares de pessoas, é considerado virtuoso. Tertuliano conclui que, pelo fato de Jesus pedir a Pedro que não use a espada, estaria assim "desarmando todos os soldados". 68

No nível nacional e racial Martin Luther King é o modelo de resistência. No nível internacional Gandhi ${ }^{69}$, que, com a sabedoria do Evangelho no Sermão da Montanha, buscou transformar os inimigos em amigos, sem humilhar, castigar ou derrotar. Foi capaz de ver a verdade inclusive no adversário, e por isso deixou de lado todo ódio, hostilidade, ressentimento e agressão, buscando libertar da violência tanto o opressor quanto o oprimido. Ele resistiu de forma não violenta contra o imperialismo britânico. Gandhi é a epifania de Jesus no mundo oriental ${ }^{70}$.

Gandhi é o primeiro homem moderno, porque fez a síntese entre o mundo oriental e ocidental. Ele conseguiu isso porque primeiro integrou sua própria personalidade através da mística hindu. Ele próprio praticou a não violência em sua vida pessoal, libertando-se da violência interior e sendo

\footnotetext{
${ }^{65}$ PfP 241ss.

${ }^{66}$ DWL 225.

${ }^{67}$ MERTON. T., Redeeming the Time, Op., Cit., p. 150ss.

${ }^{68}$ MERTON, T., Redeeming the Time, Op., Cit., p. 150.

${ }^{69}$ DWL 96, 100, 102.

${ }^{70} C G B 73$.
} 
plenamente autêntico, antes de elaborá-la em uma filosofia prática política. Mas tal prática política não impediu que sua nação, a Índia, se dividisse em dois países (Índia e Paquistão) em constante conflito e ameaçando a paz mundial.

Apesar disso, Gandhi não desespera, mas contempla a única alternativa que lhe resta: entregar a vida por seu povo. E foi martirizado por um concidadão que ele não conseguiu convencer. ${ }^{71}$ Gandhi é também um paradigma da síntese entre espiritualidade e ação sócio-política. Ele não faz dicotomia entre ambas as atividades e assim evita o secularismo da cultura e o dogmatismo da religião (a ditadura do dogma). Fervor espiritual e solidariedade compassiva devem andar juntos. ${ }^{72}$

Além de Jesus, King e Gandhi, três outros paradigmas de resistência não violenta são apresentados na obra Fé e Violência: Simone Weil, Alfred Delp e Franz Jäggerstätter. Simone Weil juntou-se à resistência francesa contra os nazistas. Merton descobre uma estranha coincidência: Simone foi tratada num hospital da Inglaterra pelo médico Tom Bennet, seu padrinho e protetor quando jovem estudante em Cambridge ${ }^{73}$. Por sua vez, D. Bonhoeffer é apresentado como modelo de "conversão ao mundo". Uma presença despercebida, que Merton considera como monástica: "oposta à presença 'clerical' que é oficial e chama a atenção para si mesma e sua mensagem" "74.

Merton considera autêntica a mística de Weil e sincera a atitude de não se filiar à Igreja (o que comporta um elemento profético). Ele admira seu não-conformismo como elemento essencial, bem como sua crítica profética à americanização da Europa depois da guerra, arrancando as raízes orientais européias. Ele transcreve um texto de Simone: "Felizes os que sofrem na carne os sofrimentos do mundo em sua época... Somos matéria humana moldada pelo tempo sob o olhar de Deus". ${ }^{75}$

Alfred Delp era padre jesuíta, que recusou apoio aos nazistas ${ }^{76}$. Foi condenado como traidor da pátria durante a guerra. Merton faz a introdução de sua obra, contrastando o caráter existencial desses escritos com uma erudição meramente acadêmica ${ }^{77}$. Delp entrou na resistência ao nazismo, parti-

${ }^{71}$ FV 40ss.

${ }^{72} S D 161$.

${ }^{73}$ DWL 214.

${ }^{74}$ DWL 86, 129, 134.

${ }^{75}$ DWL 213.

${ }^{76} \mathrm{Tt} W 249,251$.

${ }^{77}$ FV 47-68. 
cipando do "Kreisau Circle". Foi caluniado de conspirar contra Hitler. Seu crime maior, porém, como ele mesmo escreve, foi o fato de ser jesuíta ${ }^{78}$.

Delp, em sua prisão cheia de violência, encontra sentido unicamente na Oração do Pai-Nosso. "O motivo fundamental de nossa vida é a compaixão e a direção paterna. Deus é Pai, Fonte, Guia e Confortador... Quem tem fé percebe a solicitude, a compaixão e a profunda ajuda da Providência em inúmeras formas silenciosas, ainda quando é atacado de todos os lados e a situação parece desesperadora". ${ }^{79}$

Franz Jäggerstätter era pai de família na Áustria. Por objeção de consciência, recusou-se a entrar no exército de Hitler, mesmo instado por seu pároco e por seu bispo a uma atitude contrária à sua consciência ${ }^{80}$. Ele resistiu a alistar-se como combatente em favor das forças de ocupação nazista. Disse "Não" ao poder injusto e opressor e praticou a não violência. Teve o mesmo destino do padre Delp: o martírio. ${ }^{81}$

Merton entusiasmou-se com os comentários de Jägerstätter, tão lúcidos, a respeito do caráter irreconciliável entre a fé cristã e o nazismo. No entanto, as Igrejas católicas e evangélicas apoiaram Hitler quando chegou ao poder, e não apoiaram o comunismo. Merton se pergunta: Por quê? "A Igreja católica na Alemanha e na Áustria, tendo condenado o nazismo antes que chegasse ao poder, e tendo depois colaborado com ele quando chegou ao poder, certamente sabia que o nazismo está numa oposição irreconciliável com a Igreja - tanto quanto o comunismo. Por que a Igreja apoiou o nazismo e nunca o comunismo? Talvez porque os nazistas fossem mais pragmáticos em oferecer meios de transigência. Mas também, basicamente, 'por causa da propriedade". 82

Nos dias atuais, também as igrejas norte-americanas apoiaram a política belicista e imperialista de Bush, porque ele lhes ofereceu muitos privilégios, regalias e subornos, em troca do silêncio conivente com a sua economia neoliberal e sua política belicista. Subornar a Igreja é uma prática recor-

\footnotetext{
${ }^{78}$ DELP, Alfred, Prison Letters. Introdução de Thomas Merton, Nova Iorque, Orbis Books, 2004.

79 DELP, Op., cit., p. 100-101.

${ }^{80} \mathrm{TtW} 213-214$.

${ }^{81}$ Num Retiro no Mosteiro de Gethsemani pregado por Merton em 1965, o Jesuíta Padre Dan Berrigan ficou tão impressionado com o exemplo de Franz Jägerstätter, que se tornou até hoje um Profeta em favor da paz e combatente da resistência cristã não violenta contra a interferência do governo norte americano em outros países, e em favor do desarmamento total, promovendo desobediência civil e protestos junto ao Ministério da Defesa em Washington, tendo sido preso inúmeras vezes. Cf., DEAR, John. Apostle of Peace: Essays in Honor of Daniel Berrigan, Nova Iorque, Orbis Books, 1996, p.5.

${ }^{82}$ DWL 165.
} 
rente do FBI e da CIA, desde longa data, visando torná-la uma poderosa aliada na luta contra o comunismo. David Yallop confirma isso quando diz: "Nos anos 50 e 60 (do século passado), a CIA proporcionou apoio econômico a muitas atividades promovidas pela Igreja Católica, de orfanatos a missões. Milhões de dólares eram dados a bispos e monsenhores todos os anos... Para impedir que a Itália levasse ao poder um governo comunista eleito democraticamente... despejavam milhões de dólares no país". ${ }^{83}$

Os únicos grupos católicos a opor resistência à política e à economia de guerra nos EUA estão ligados de um modo ou outro ao nome e ao exemplo de Merton. Por isso ele pagou com a própria vida seu testemunho profético. Seus passos foram vigiados pela CIA, alertada pelos católicos ultraconservadores de Louisville-Kentucky, que o acusaram de comunista e antipatriota, queimando publicamente seus livros em praça pública. A ocasião chegou para eliminá-lo quando Merton foi a Bangcoc para um encontro entre monges cristãos e budistas. Ele proferiu palestra no dia 10 de dezembro de 1968, às 10 horas da manhã exatamente sobre "Marxismo e Perspectivas Monásticas. ${ }^{84,}$

A palestra durou cerca de duas horas, e foi acolhida entusiasticamente. Ele apresentou sua tese de que os ideais marxistas se concretizam unicamente nos mosteiros, onde cada um recebe segundo suas necessidades, e contribui segundo suas possibilidades. Diz ele textualmente: "O comunismo consiste em uma sociedade em que cada um dá segundo sua capacidade e recebe segundo suas necessidades. Se refletirmos dois segundos nesta definição, veremos que é a definição da comunidade monástica... O mosteiro é o único lugar real onde isso se pode realizar". ${ }^{85}$

A palestra da manhã seria debatida às duas horas da tarde daquele mesmo dia 10 de dezembro. Mas estranhamente, Merton não compareceu. Quando arrombaram a porta do seu quarto, encontraram-no já sem vida. Tinha sido eletrocutado por um fio desencapado, após tomar banho. Um assassinato perfeito tramado pela CIA, sem deixar indícios! Uma novela foi escrita sobre a morte de Merton, em que conta com detalhes como dois detetives conseguiram entrar na cabana da Cruz Vermelha, onde ele estava hospedado, e armaram um complô que o mataria ${ }^{86}$. Finalmente o Império con-

\footnotetext{
${ }^{83}$ YALLOP, David. Em Nome de Deus: Uma investigação em torno do assassinato do Papa João Paulo I, Rio de Janeiro, RECORD, 1984, p. 134.

${ }^{84}$ HART, Patrick (org.), The Other Side of The Mountain: The End of the Journey, Nova Iorque, Harper Collins Publishers, 1999, p.XVIII, 263, 266, 268, 298.

${ }^{85}$ MERTON, T., O Diário da Ásia, $2^{\text {a }}$ ed., Belo Horizonte, VEGA, 1978, p. 261-262.

${ }^{86}$ GOODSON, Bill. The Bossuet Conspiracy: A Novel, Nova Iorque Universe, Inc., 2003.
} 
seguiu se livrar do monge incômodo, ateu do ídolo nacionalista montado sobre a Religião Civil. Washington vigiou-o com sucesso.

O Império norte-americano há de passar, como outros impérios passaram. Mas a memória bendita de Merton atravessará os séculos como símbolo de uma humanidade superior, inteiramente dedicada a Deus e aos humanos. A violência que ceifou sua vida é a mesma sofrida por milhões de pessoas, diariamente, pelo mundo inteiro, seja pelas balas perdidas, seja pelas armas inteligentes, ou pela mãe de todas as bombas, a mais maldita de todas. Ao entregar a vida como conseqüência da mensagem que anunciou, Merton tornou-se um precursor da espiritualidade da libertação latino-americana, unindo contemplação e ação, mística e profecia. A morte martirial do Eremita de Gethsemani exatamente quarenta anos atrás, inspira-nos hoje a resistir, em palavra e ação, ao projeto de dominação mundial, praticado pelo Império Americano, águia devoradora prestes a se lançar sobre as demais nações para explorá-las, e semeando a guerra, o ódio e o terror por onde passa.

\section{Conclusão}

Quarenta anos depois da morte de Thomas Merton, sua mensagem lamentavelmente continua a ser extremamente atual. $\mathrm{O}$ mundo se tornou mais perigoso ainda. Bombas químicas, biológicas e atômicas ameaçam a própria sobrevivência do Planeta, e causam danos irreparáveis nos seres humanos e no meio ambiente. O desafio de promover a espiritualidade da paz hoje bate de frente com estratégia vigente de desfechar o primeiro golpe contra o inimigo, antes que ele nos ataque. O Sermão da Montanha é uma radical negação desta estratégia, que na prática substituiu a mensagem evangélica de Jesus a respeito do amor ao inimigo.

A mensagem de Merton foi silenciada por seu Abade Geral e pela hierarquia católica de então, que era a favor do uso da bomba atômica para destruir os comunistas. A crise internacional provocada pela Guerra Fria preocupa e interpela o seu ser monge, que considera ser sua tarefa prioritária fazer tudo ao seu alcance para abolir a guerra ${ }^{87}$. Seu exemplo inspirou outros ativistas, como Daniel Berrigan, no empenho pela paz a nível mundial e nacional. No nível pessoal, ele prega o desarmamento dos espíritos, abolindo as secretas agressões dirigidas contra as pessoas com as quais convivemos. No nível internacional prega a resolução dos conflitos pelos organismos ad hoc, descartando a violência como norma.

${ }^{87}$ SL 215. 
A não violência é a atitude mais eficaz para resistir ao mal e minimizar a violência generalizada na sociedade, no mundo e dentro de nós mesmos. Ela supõe ascese, descrita pelas Mães e Pais do Deserto, que consideram a não violência como pureza de coração, meta da espiritualidade ${ }^{88}$ Gandhi, King, Nowen, Berrigan, John Dear e Merton, entre outros, a encarnaram radicalmente. Ela supõe também a abertura que nos capacita a aprender do adversário, a vê-lo na base de uma comum humanidade conosco. A arrogância de pretender ter sempre razão torna-nos inflexíveis e nos faz perder a capacidade de ver a verdade. A via da não violência supõe compaixão que nos torna flexíveis ao outro, recusando brigar por palavras, numa atitude arrogante. Ser não-violento é deixar-se iluminar pela verdade do outro, ainda que ele seja adversário.

A indignação de Merton se dirige contra as superpotências em conflito, compartilhando ambas da mesma loucura, estupidez e falta de compaixão, como que movidas por diabólicas forças sobre-humanas. Vê como demência o afã de preservar a paz construindo armas nucleares e abrigos subterrâneos para se proteger. Chega a imaginar inclusive os monges fugindo para dentro desses abrigos, cada um trazendo consigo o seu queijo, produto do mosteiro, ou até, ironicamente, tentando impedir que outros procurem abrigo no mesmo lugar. E a resposta que dá é que a Igreja deve seguir a estratégia da não-violência para abolir a guerra, bem como incentivar a resolução dos conflitos internacionais mediante o diálogo nos foros internacionais. Mas também orar, pois a paz é um dom que vem do alto e precisa ser suplicada. Orar e resistir!

\section{Abstract}

Thomas Merton was one of the best known spiritual masters of the XXth Century helping many people to have a deep and healthy experience of God. He was also a radical critic of the War of Vietnam, through his speeches, articles and books. Following Jesus along the road to discipleship, as a monk, priest and hermit, he learned that life is meaningful only when invested for God (mysticism) and for humanity (compassion). The openness to God means contemplation of His glory spread in creation and human beings, images of Christ. In order to rescue their dignity, Merton was involved in issues of peace and justice in a world that uses violence as a resource for the solution of international conflicts. For this he urges those who believe in God to promote the spirituality of peace, through non violent means, resis-

${ }^{88} \operatorname{SoR} 113$. 
ting to evil, praying for the enemies, instead of destroying them in a first strike. Non violent figures such as Jesus, Gandhi, Luther King, Delp and others were inspiring to him. He was a prophet that challenged the conformism both of the catholic hierarchy and of Christians in USA.

For that reason, his books were burned publically downtown in Louisville, and his steps watched by FBI and CIA, who successfully eliminated him. His life, works and martyrdom make him an icon of a superior humanity totally devoted to God and human beings, and also made him a precursor of our Latin American spirituality of liberation, uniting a deep experience of God with a total commitment in social issues aiming that His will be done, violence be eliminated, and peace replenish the Earth.

Getúlio Bertelli

gberteli@lycos.com

Doutor em Teologia pela PUC-Rio

Professor Adjunto na UNESPAR - Campus FAFIPAR em Paranaguá,

Paraná 